\title{
エナメル上皮腫の再発と組織学的変化
}

\author{
久保田文良・本間 学・山田哲 司* \\ 大久保滋郎*・松 田 登*
}

\section{Recurrence and histopathologic changes of ameloblastoma}

\author{
Fumiyoshi Kuвota - Manabu Homma - Tetsuzi YamadA* \\ Shigeo Ookubo* - Noboru MatsudA*
}

\section{はじめに}

エナメル上皮腫は䫕骨内に発生し，膨脹性に緩慢な増 殖を示す良性腫瘍である 壊し，姑息的な療法では症例の $50 \%$ 近くが局所再発を起 こし，臨床的には準悪性として取り扱われ，䪽骨部分切 除あるいは顎半側離断切除術などを余儀なくされる症例 が多い。

著者らはエナィル上皮腫36症例について検索する機会 をもったが，その中で遭遇した再発 5 症例の腫場組織像 に二，三の興味ある所見を得ることができたので報告す る.

症例

\section{症例 1}

36歳，男性. 27 歳のとき右側下䫇臼齿部の腫脹のた め, 同部より垔胞状のるの $6 \sim 7$ 個の摘出術をらけた. 10年後 (36歳), 無痛性の腫脹が同部に再び現われ，上

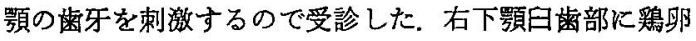
大の腫脹があり，粘液様の液体を流出する荛胞性の腫溜 が顎骨内に発見され，下罘骨半側離断術をらりた。初回 の尰煌摘出から再発手術までの経過期間は 10 年であっ た.

再発摘出組織は上皮性腫煌細胞からなる大小不規則な

群馬大学医学部第 1 病理学教室（主任：石田陽一 数授)

* 群馬大学医学部菌科口腔外科（主任：松田 登教 授)

First Department of Pathology, School of Medicine, Gunma University (Chief: Prof. Yoichi Ishida)

* Department of Dental and Oral Surgery, School of Medicine, Gunma University (Chief: Noboru Matsuda)

受付日：昭和52年10月24日

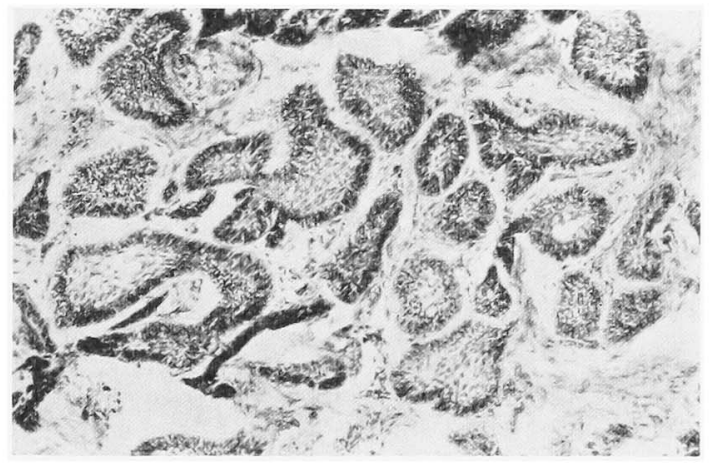

写真 1 基底細胞盾様の胞巣（症例 1)

滤胞状胞巣が線維性基質内に分布した慮胞型エナメル上 皮腫で,一部に網状型の細胞索をつくっていた. 細胞胞 巣のいずれる円柱状細胞が間質に接して棚状化配列して 扣り，胞策中心部では多角形や不正型の細胞が密炕分布 した基底細胞腫様の概観を呈する胞巣が多かった（写真 1). エナメル䯣様に星芒状細胞が粗に配列する胞巣も認 められる。実質内部も顆粒細胞が多数に現われた顆粒細 胞型胞巣もある. 濾胞周囲の結合織には硝子化が部分的 にあり，また，多数のリンハ球浸潤を認めた。

症例 2

53歳，男性. 39歳時に右下罰田歯部の膨隆に気づき， 3 年後に同部の搔爬をらけた，50歳になってから，再び 右下䫇の尰脹がみられ，53歳時には眼窩から口唇にかけ ての麻瘦が現われ，エナメル上皮腫の再発の診断で下顥 骨半側離断術をらけた，搔爬術から再発手術までの期間 は11年であった。

初回提爬時の組織は扁平上皮の性格を示す上皮細胞が 網状の細胞索をつくり，線維性基質内に增殖した網状型 エナメル上皮腫であった(写直 2). 細胞索は細胞密度の 高いところでは棘細胞様構造をとり, 細胞密度の低い一

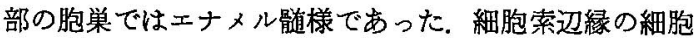
は不定形で，円柱状細胞の排列は明らかでなかった，間 質は水尰性であり，好中球浸閵が中等量認められた，再 発手術した下顎骨には，右下䫇臼歯部から上行枝に拡が 


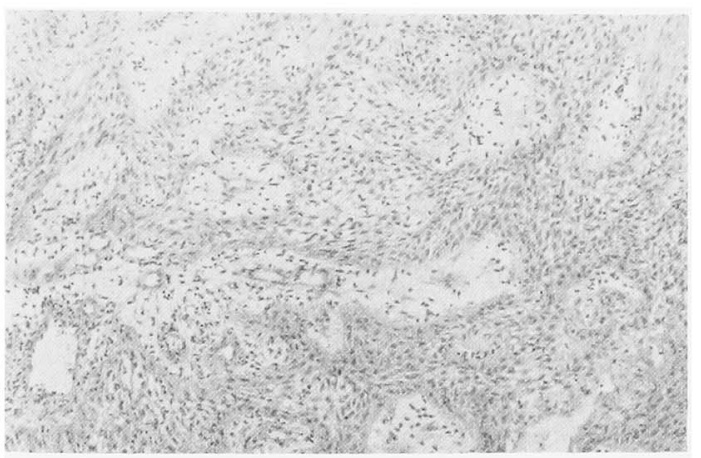

写真 2 網状稩胞索をつくるェナメル上皮腫 （症例 2,初発組織）

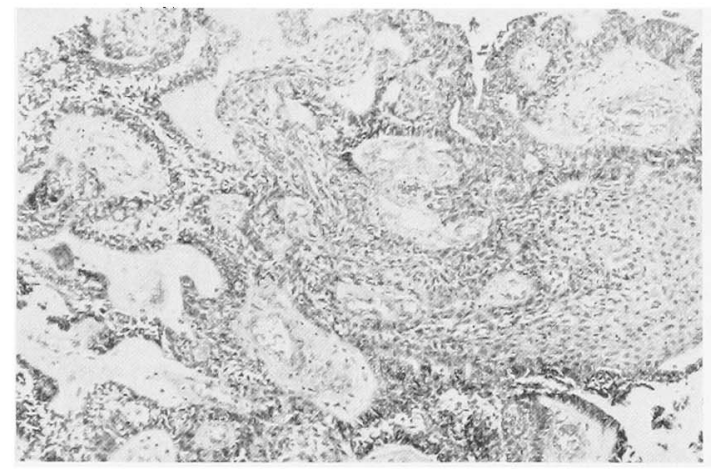

写真 3 勫胞索辺緑の円柱状勫胞のフェンス 状排列（症例 2，再発組織）

る鵎卵大の多房垔胞が認められ，一部に海綿状実質を伴 っていた，組織学的には，やや非定型的な網状型で，細 胞索の辺縁や周辺帘でコルベン状や発蕾状に細胞索が突 出し，ところどころで濾胞型の胞栄をつくっていた，初 回の像と異なり，上皮細胞索や胞巣の周辺帯の細胞が円 柱状であり，核も類円形で基底膜より遠位に位置してい た（写直 3). 俩成する細胞の多くは胞体か，やや塩基 性であり，細胞密度は比較的高く，しばしば棘細胞巣を つくり，また，角化球をむつ胞篓も認められた。

\section{症例 3}

36歳，女性．25歳時に右下額の無搅性尰脹に始まり，

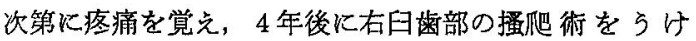
た，その後，経過は良好であったが，36歳になって右頓 部に無痛性腫脹が現われ，腫嫁再発で下買骨半側離断術 をらけた。初回の播爬から再発手術までの期間は 7 年で あった。

再発連瘍は在偶角部を中心にした一部海綿状充実部を 伴ら硔胞性のものであった，組織は上皮性細胞が大小の 類円形からヒトデ形にいたる，ささざまの形の滤胞型胞 染をつくって線維性基質内に密に分布していた。すべて

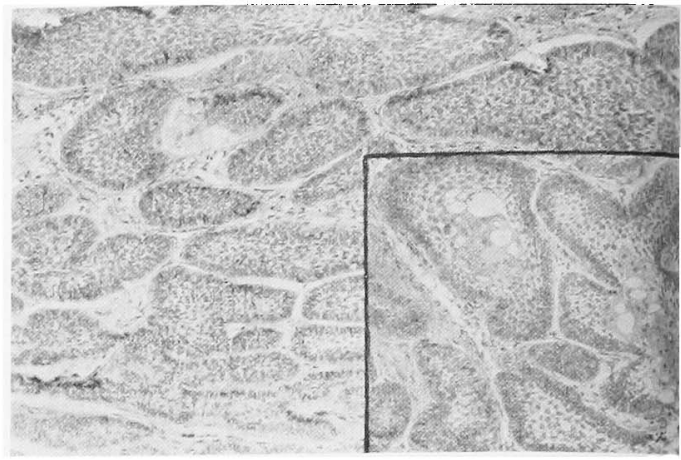

写真 4 基底稩胞腫様胞单と重扁上皮化生を 示す胞巣 (症例 3 )

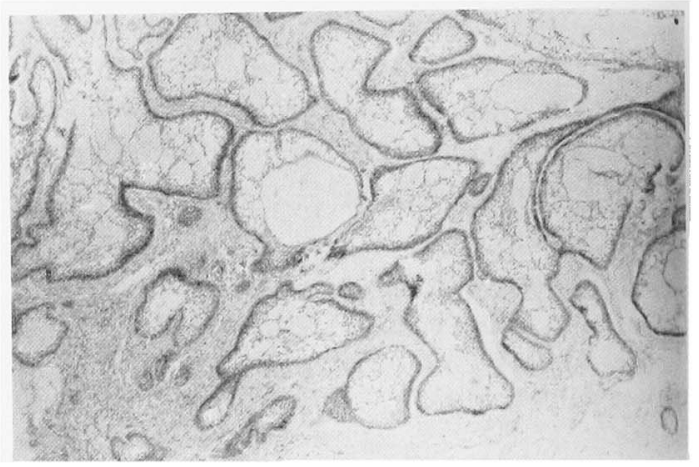

写真 5 エナィル䯣露胞をるつ滤胞型エナィ ル上皮腫（症例 4 。初発組織）

の細胞胞巣は周辺に円柱細胞が排列していた，胞巣中央 では多角形や星芒状の細胞が粗に分布したニナメル骵類 似像を是しているものもあるが，小型の胞巣では細胞が 比較的密に分布 し，基底細胞腫様の構造をとり(写真4)， 大型の胞䍒は专質細胞の角質変性を伴ら空胞化により， いわゆる膠質細胞䘫胞を形成するものが多い，顆粒細胞 型胞楽もある中型から大型の胞㫦では重扁上皮化生を示 し，大型の踓胞壁は韭薄な上皮細胞層で内張りされ，基 底部では発蕾状に上皮細胞索が基質内に突出伸展してい る像がところどころでみられた。 寸なわち基底細胞腫様 の概観を示す胞栄と賿質細胞変性を示し, 重扁化生を伊 う胞楽が主体で，エナメル髄様構造をとる胞栄はそしか った。

\section{症例 4}

61歳，女性. 39歳のときに右煩部の無痛性腫脹に気つ’ き，1年後に右下䫑の買辺縁切除術をうけ，経過は良好

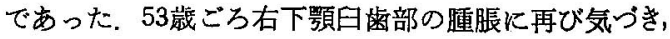
次第に下顎枝にかけて尰脤が広がり，王痛を諮めるよう になり，54歳のときに右下䪽骨半侧離断術をうけた。 れから4年後に右眼简外上方に拇指頭大の尰瘤 が 発生 


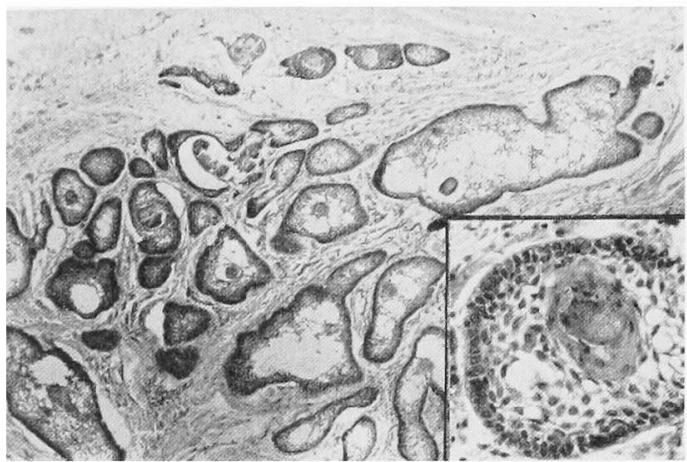

写真 6 石灰化と角化のみられる大小の满胞 (症例 4 ，再発組織）

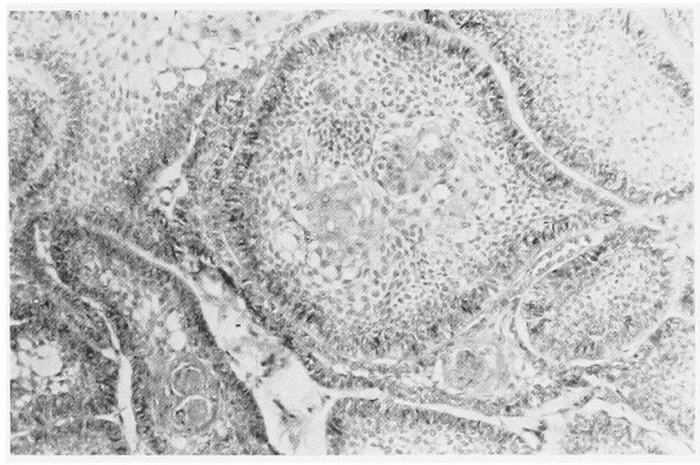

写真 7 重層扁平上皮型を示すェナメル上皮腫 （症例 4 。再々発組織）

し，增大したので61歳のとき摘出した，その後は，現在 まで経過良好である．初回の靧辺縁切除から右下䫇半側 離断術までの経過は13年であった。

初回の手術組織標本 (40歳時) は上皮細胞が大小不規 則な形の胞栄をつくり，密な線維性基質内に增殖した濾 胞型のエナメル上皮腯で，しばしば大小のエナィル䯣覇 胞をつくっていた（写真 5). 一部には重扁上皮化生巣 と角化球の形成がみられた，再発による切除下頻骨 (53

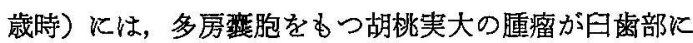
あり，一部は充実性であった．組織学的には初回と同様 に濾胞型エナメル上皮腫であったが，やや線維性基質の 硝子化が増強し, さらに滤胞内細胞密度が増加し, 重扁 上皮化生，濾胞中心の角質変性，石灰化が目だっていた (写真 6). 第 3 回の手術摘出物 (61歳時) は中小の裹胞 からなる胡桃実大の腫諨組織で，周囲軟部組織と軽度に

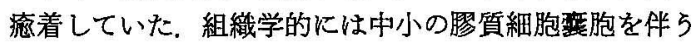
濾胞型胞巣が主体をなし，濾胞内には角化や石灰化巣が みられた，全体に譨胞形成が著明であるが，小型〜中型 の胞栄は細胞密度が高く，しばしば棘細䝭層を伴う重扁 上皮構造をとっていた（写真 7).

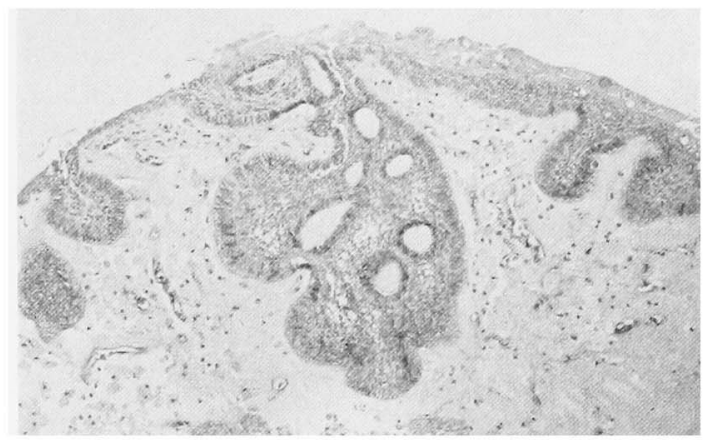

写真 8 大型要胞壁から上皮細胞索形成（症例 5)

\section{症例 5}

38歳，男性. 26 藏洔に左下額部の腫脹に気ついたが， 疼痛のないまま放徝した３3藏時に口唇の麻瘦感が現わ れ，左下顎の腫脹があるので愉查をらけ，左下靧大田歯 根尖部近く 18 の埋伏と拇指頭大の骨透完像が発 見さ れ， $\overline{78}$ の拔歯とその部の掻爬をうけたそそれから 5 年

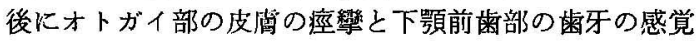
消失が現われ，精査したところ，左下顎大臼雪部から筋 突起にかけて骨吸収像があり，7月に顎骨半側離断術を らけた。提爬から再発手術までの経過は 5 年であった。

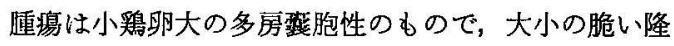
起をもった粗粘な㯎胞面からなり，一部平滑であった， 組織学的には硝子化を強く示寸密な結合織内に, 重扁上 皮類似の薄い上皮層が被覆する大型の暴胞と濾胞型拈よ び網状型が混在する組織からなっていた．小型の胞樂 は，しばしば大型囊胞壁の上皮細胞と連続しており，ま た大型雯胞壁の上皮細胞層が発蕾状に基底部から線維性 基質内に突出している像がみられた(写真 8). いずれる 胞巣周辺の上皮細胞は円柱状で, ほぼ一層密に排列して いた.

\section{考察}

エナメル上皮腫は術後の局所再発のきわめて高い腫瘍 で，その再発率は保存療法で50\%前後, 根治的潦法で10 \%前後とされている。.もちろん再発率は治療法の適否， follow-up の期間などでかなりのばらつきがみられるが, 多くの報告で局所搔爬が最も高い再発率を示している.

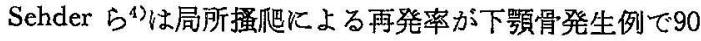
$\%$, 上額例 $100 \%$ ，部分下靧骨切断で $22 \%$, 半側下罘骨離 断で0\%であったと述べており，また，Mehlisch 5゙も 搔爬では $90 \%$ 近い再発率があり, $3 \mathrm{~cm}$ 以下の小重瘤では 摘出術に効果があるが, $5 \mathrm{~cm}$ 以上の大きさの腫瘤では顎 切除が最もよい結果を得たと記載している。ここに揭げ た再発 5 症例も，5ち 4 例が摘出または掻爬などの保存 的療法をうけたものであり，保存的療法をうけた患者に 
再発の機会の多いことを示している。 また, 初回の療法 から再発までの期間がすべて10年前後と長く, エナメル 上皮腫では, 再発有無の判定には術後10年以上の followup が必要であろう.この点については Mehlisch ら5) long-term follow-up の必要性を強調して拈り，また， 寺崎6)も15年前後の経過観察が必要であるうとしてい る.

㴿骨内エナメル上皮腫の際，摘出や搔爬によって腫陽 組織を十分に剔出するよう努力しても, 結合織性の被膜 を越兄て周囲の顎骨骨髄腔や Havers 氏管内に浸潤した り，骨組織を不規則に吸収している腫瘍組織は，これら の保存的治療から取り残される可能性が高く，このよう な症例では，再発の機会が多いことは推定される。すな わち, 腫湯自体の周囲骨質内への浸潤性増殖傾向の程度 が治療法とともに再発の鍵を握っているといえる。平 出 ${ }^{7)}$ は宮崎・荒井の分類 ${ }^{8)}$ に基づき症例を組織学的に検 討したところ，I 型の組織型を示す症例の $60 \%$ ， II 型の $33 \% ， \mathbb{I I}$ 型の $28.7 \%$ が再発例であった。 また，全割組織 標本による腫瘍增殖様式の観察では, 分化の程度の高い 型（III型）ほど膨脹性増殖を起こしやすく，これに反 し，低分化型（I 型）ほど侵襲性増殖を起こしやすく， 再発傾向が高いと報告している，山本ら ${ }^{9)}$ も同様に，再 発は分化の程度が低いI 型に高い傾向がみられたと記載 している. 小野 ${ }^{10)}$ はエナメル上皮腫を歯堤期, 蕾状期, 鐘状期の 3 つの発育型に分類し，32症例について検討を 加兄, そのらちの 5 再発例の組織型は蕾状期発育型に属 するが，いずれる胞巣がかなり広い範囲にわたり周囲骨 髄腔内に侵入発有しており, しか子実質胞巣淀型的な エナメル器類似の構造をもつ部は少なく, 基底細胞の増 殖が著明で，エナメル髄細胞または星細胞層との間に移

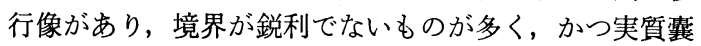
胞形成などの变化は認められず,一見, 低分化的な感が あったと記載している。ささらに彼は再発例はなかった が, 最も分化の低い歯堤状発育型が周囲骨髄腔中に発育 寸る所見が強く, ほかの組織型に比し再発の可能性が高 いだろうと述べている.著者らの検討した 5 症例では,

1. 組織像は多彩であるが, 全般的にみて濾胞型胞巣を もつものが多く，網状型を呈するものでも濾胞型胞巣と の混在や移行像がみられる。.2. 組織型のいかんを問わ ず胞巣辺縁には, 円柱状細胞がフェンス状に密に排列し ている. しかし， 3. 定型的なエナメル髄様構造に乏し く, 4. 胞巣を構成する上皮細胞の密度がしばしば高く， 高度なものでは基底細胞上皮腫様の像を呈している. 5. 重扁上皮化生が目だつ傾向にある。6. 実質糞胞形成は 膠質細胞裴胞が主体である。 7. 中型〜大型の胞巣では, ときに発蕾状に間質内に上皮細胞が突出している。 8. 間 質は密な線維性結合織からなり, 間質の水腫の高度な例 は少なく、䧶胞形成はない,などの共通した像が認めら れた. この所見は, 再発腫瘍組織ではエナメル器への分
化の程度が低い濾胞型の形態をとる傾向が強いことを示 唆しているように思われる。濾胞型エナメル上皮腫が網 状型に比し，やや高い再発率をるつことは，すでに寺崎6) が記載して扣り，その理由として網状型は単房性の性状 を示すため完全に择爬することができるのに対し, 濾胞 型では多房性の像を示し, 完全な摘出が困難なため, よ り高い再発率を示すのであろらと推論している.

再発腫痬の組織像は，基本的には原発腫場のそれ之同 じであるとされているが，再発を絽り返し起こした場 合, かなり組織像を変えることがある ${ }^{11}$. 著者らは初発 腫瘍と再発腫瘍の両者の組織像を観察できたのは, わず か 2 例であるため, 十分な検討はできなかったが，基本 的な組織型は初発と再発腫場組織と同じであった。 しか し, 組織分化の観点では若干の相違がみられた。症例 2 の初発腫場は不定形の辺縁細胞で間質と境された網状の 細胞索をつくった網状型エナメル上皮腫であったが，再 発腫場では間質と接する辺縁細胞が円柱状となり,さら に細胞索の辺縁や周囲帯でコルベン状に細胞索の突出が 間質に向かってみられ，変形した網状型エナメル上皮腫 像を呈していた。また，ところどころに滤胞型胞巣をも ち, 細胞索内には初発腫瘍ではみられなかった重扁上皮 化生巣が認められた。症例 4 の初発腫瘍は高度のエナメ

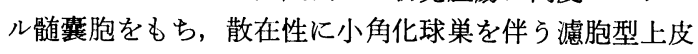
腫であったが, 再発腫場は細胞密度の高い重扁上皮化生 を強く示す中等大の胞巣を主体とした滤胞型の像であ り, 䧶胞も膠質細胞襄胞を主体としていた。すなわち, 初発腫瘍に比し再発腫湯では胞巣の細胞密度の増加, 重 扁上皮化生の進行, 定型的なエナメル䯣様構造やエナメ 儿髄裂胞の減少とそれに代わる膠質細胞囊胞の増加，な どが認められた．エナメル上皮腫は再発によって低分化 型の濾胞型エナメル上皮腫, WHO 分類 ${ }^{11}$ の棘細胞型や 基底細胞型の組織像を示す場合もあると思われる。

\section{ま と め}

エナメル上皮腫の再発症例を組織学的に検討した， 1. 再発腫缶は組織学的に濾胞型を示し, 胞巣にエナメル䯣 様構造がそしく, 重扁上皮化生が目だつなど共通の特徵 が認められる，2．２例の再発腫愓を原発腫惶と組織学 的に比較したが, 再発腫瘍はいずれも初発腫瘍の基本像 を残しているが，より低分化型の胞巣からなっていた。

稿を終わるにあたり，終始ご指導とご校閲をいただい た石田陽一教授に心から深謝いたします。

\section{文献}

1）石川梧朗, 秋吉正豊：口腔病理学 II, 永末書店 京都, 1971, 908頁. 
2) Baden, E.: Odontogenic tumors. Pathology Annual 6: 4871971.

3) Gorlin, R.J., Goldman, H.M.: Thoma's Oral Pathology. ed 6, Mosby Co, St Louis, 1970, p 482.

4) Sehder, M.K., Huvos, A.G., Strong, E.W., Gerold, F.P., Willis, G.W.: Ameloblastoma of maxilla and mandible. Cancer 33: 324 1974.

5) Mehlisch, D.R., Dahlin, D.C., Masson, J.K.: Ameloblastoma: A clinicopathologic report. J Oral Surg 30: 91972.

6）寺崎太郎：エナメル上皮腫に関する臨床病理学
的研究. 阪大畨誌 4: 12771959 .

7）平出释布：エナイル上皮腫の臨床的ならびに病 理学的研究. 口外誌 4:214 1958.

8）宮崎吉夫，荒井元正：㢷瑯上皮腫の組織由来に ついて. 口腔病理学会雑誌 13: 3491939.

9）山本浩幄，高木実，他：エナメル上皮腫の臨 床病理学的検討. 日大幽学 49:891975.

10）小野史郎：エナメル上皮腫の発育に関する形態 学的研究. 福岡医誌 51：991 1960.

11) Pindborg, J.J., Kramer, I.R.H.: Histologic typing of odontogenic tumors, jaw cysts, and allied lesions. WHO, Geneva, 1971, p 24. 